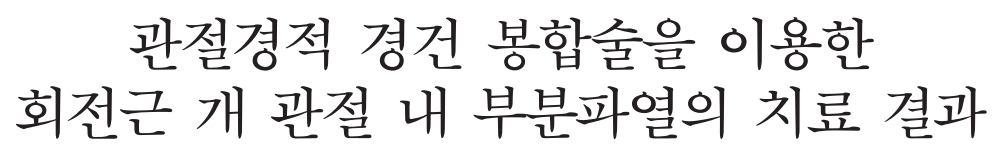

원광대학교 의과대학 정형외과학교실, 원광의과학 연구소, 순천플러스 정형외과*

김종윤 · 전철홍 · 김정우 · 강홍제 · 송승엽 · 최윤홍*

\title{
Clinical Results of Arthroscopic Transtendon Suture Technique of Partial Articular Surface Tendon Avulsion Lesion
}

\author{
Jong Yun Kim, M.D., Churl Hong Chun, M.D., Jeong Woo Kim, M.D., \\ Hong Je Kang, M.D., Seung Yeop Song, M.D., Yoon Hong Choi, M.D.* \\ Department of Orthopedic Surgery, School of Medicine, Wonkwang University, Iksan, Korea \\ Department of Orthopaedic Surgery, Suncheon Plus, Suncheon, Korea*
}

\begin{abstract}
Purpose: To analyze clinical results of arthroscopic trans-tendon repair in a partial articular-side rotator cuff tear.

Materials and Methods: Of 31 patients presenting with partial intra-articular rotator cuff tears between April 2006 and January 2010, we selected 24 who had received arthroscopic trans-tendon repair. The average age of patients was 55 (27 75) and the average follow-up period was 37 months (19 64). There were 10 men and 14 women and all had at least a $6 \mathrm{~mm}$ tear categorized as Ellman grade 3. Change in range of motion, VAS, ASES, Constant score, and ultrasonographic findings were evaluated postoperatively.

Results: The average forward elevation range prior to surgery was $150.2( \pm 6.67)$ and it improved to 170 ( \pm 5.32$)$ by the last follow-up $(p<0.001)$. The average VAS score prior to surgery was $7.38( \pm 1.38)$ and it decreased to $3( \pm 1.38)(p<0.001)$. The Constant score before surgery was $49.25( \pm 5.65)$ and it increased to $73.81( \pm 5.64)$ by the last follow-up $(p<0.001)$. The ASES score before surgery was 39.59 $( \pm 12.27)$ and it increased to $80.56( \pm 11.36)(p<0.001)$. At the last follow-up, 21 of the 24 patients were satisfied with the result. However, 3 patients were unhappy and had mild pain. On ultrasonography, 22 patients (91.66\%) showed improvement without re-rupture, while the other 2 patients (8.34\%) showed an with improved symptoms.

Conclusion: In a partial rotator cuff tear in an articular-side lesion, the arthroscopic transtendon suture method shows excellent clinical and ultrasonographic results for at least eighteen months.
\end{abstract}

Key Words: Shoulder, Rotator cuff, Partial tear, Arthroscopy, Transtendon suture

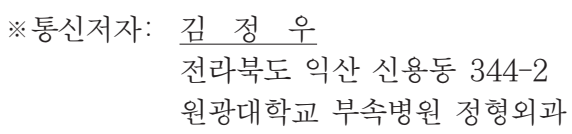

Tel: 063) 859-1360, Fax: 063) 852-9329, E-mail: serina@wonkwang.ac.kr 접수일: 2011년 9월 30일, 1차 심사완료일: 2011년 10월 13일, 2차 심사완료일: 2011년 11월 4일, 3차 심사완료일: 2011년 11월 13일, 게재 확정일: 2011년 11월 20일 *본 논문은 2011년도 원광대학병원의 임상연구비의 지원을 받아 이루어졌음. 


\section{서 론}

회전근 개 파열은 성인에서 견관절 통증의 흔한 원인 이며, 전층을 침범하지 않는 부분 파열에서도 통증 및 기능 저하가 나타날 수 있는데, 특히 야간 통증이 심하 고 운동 제한을 동반하는 경우가 많은 것으로 알려져 있다. ${ }^{1)}$ 회전근 개 부분 파열이 발생하는 원인은 정확히 밝혀지지 않았지만, 관절낭면에서 더 많이 발생하며, Snyder가 처음으로 회전근 개 관절내 부분 견열성 파 열 (PASTA; partial articular surface tendon avulsion)로 기술하였다. ${ }^{2}$ 부분 파열의 치료 방법에 대 해서는 논란이 있으며, 일반적으로 6 개월 이상 활동조 절, 통증 조절 약물, 스트레칭 운동, 스테로이드 주사 등의 보존적 치료를 시행할 수 있다. 하지만 보존적 치 료에 호전이 없는 경우 변연 절제술, 견봉하 감압술, 회전근 개 봉합술 등이 시행될 수 있으며, 최근에는 봉 합 재료와 관절경적 술기가 발달함에 따라 관절경적 회 전근 개 봉합술에 관심이 모아지고 있다. 봉합술의 방 법은 크게 두 가지로 나뉘는데, 점액낭 측의 건재한 회 전근 개를 보존하면서 봉합 나사못을 이용하여 봉합하 는 경건 봉합술과 남아있는 건을 완전 파열로 전환한 후 봉합하는 방법이 있을 수 있다. 저자들은 남아있는 건재한 회전근 개를 보존하면서 관절경적 경건 봉합술 을 시행하고, 그 임상적 및 초음파를 이용한 결과를 알 아보고자 하였다.

\section{연구 대상 및 방법}

\section{연구 대상}

2006년 4월부터 2010년 1월까지 회전근 개 관절 내 부분 파열로 진단되어 보존적 치료에도 통증의 호전이

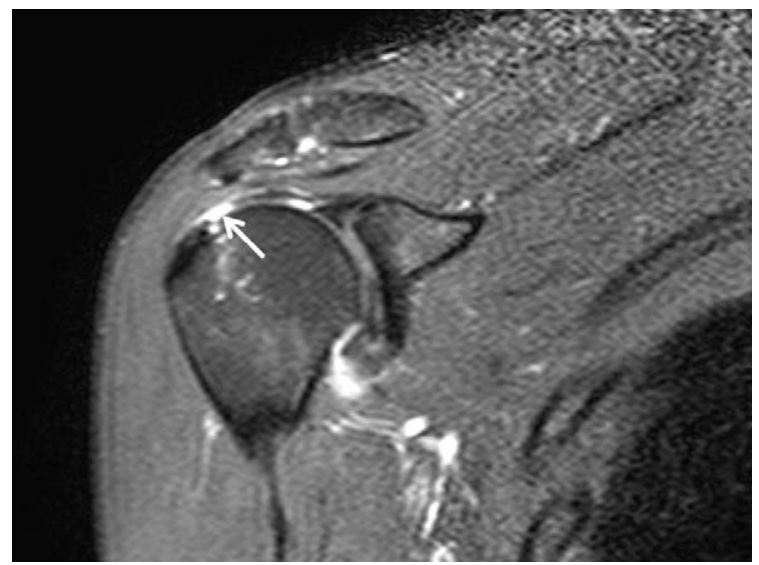

Fig. 1. Preoperative magnetic resonance imaging scan shows a typical PASTA lesion (white arrow).
없어 수술을 시행했던 31예의 환자 중 $50 \%$ 미만의 파 열이 있어 변연 절제술만 시행한 경우, 윈위 쇄골단 절 제를 시행한 견봉 쇄골 관절염 환자, 관절와 순 복원을 시행한 환자, 이두 건 장 두의 건 절제술 또는 건 고정 술을 시행한 환자는 대상에서 제외하였고, 회전근 개 관절내 $50 \%$ 이상의 파열이 있어서 관절경적 경건 봉합 술 (transtendon suture technique)을 시행 받은 24 예의 환자를 대상으로 하였다 (Fig. 1). 수술은 동일한 한 사람에 의해 시행되었으며, 탐색침을 이용하여 파열 의 깊이를 측정하였다. 수술 후 평균 추시 기간은 37 개 월 (19 64)이었으며, 수술 시 환자의 평균 연령은 55 세 (27 75)였고, 남자가 10 예, 여자는 14 예였다. 우 측 견관절이 17 예, 좌측 견관절이 7 예였으며, 우세수 18예, 비 우세수 6예였다.

\section{평가 방법}

수술 전에 신체 검사를 다시 시행하고 최종 추시 시 수술적 결과에 대해 분석하였다. 신체검사로서 견관절 운동 범위는 전방 거상, 외회전, 내회전을 측정하였다. 임상 결과로서 주관적인 통증은 Visual analogue scale (VAS)을 이용하여 측정하였고, Constant 점수 및 ASES 점수를 통해 환자의 기능 평가를 측정하여 이환된 견관절에 대한 수술 전과 최종 추시 시의 상태 를 평가하였다. 영상학적 검사로 모든 환자에 대해 수 술 후 평균 37 개월 $(19 \sim 64)$ 에 초음파를 이용하여 치 유 여부를 판단하였다.

\section{수술 및 재활 방법}

모든 수술은 동일 시술자에 의해 이루어졌으며, 전신 마취 하에 해변의자 (beach-chair position) 로 시행 하였으며 출혈을 최소화하기 위해 저혈압 마취를 시행 하고, 펌프를 이용하여 수압을 유지하면서, $1: 1000$ epinephrine $1 \mathrm{ml}$ 를 3000cc 세척용 생리 식염수에 혼 합하여 사용하였다. 견봉의 후외측연의 $2 \mathrm{~cm}$ 하방 및 $2 \mathrm{~cm}$ 내측에 후방 삽입구를 만들어 도관 삽입 후 관절 경을 삽입하여 관절내 회전근 개의 파열을 확인하였다 (Fig. 2), 전방 삽입구를 통해 탐색침을 삽입하여 상완 이두 장 건의 병변과 상부 관절와 순의 상태를 관찰하 고, 관절내 회전근 개 파열이 전층 파열인지 부분층 파 열인지 확인하였다. 부분층 파열의 경우 탐색침을 이용 하여 파열의 깊이를 측정하였다. 후방 삽입구에서 견봉 하 공간으로 관절경을 다시 삽입하고 외측 삽입구를 만 들어 시야를 확보하면서 견봉하 점액낭쪽 파열의 유무 를 확인하였다.

견봉하 점액낭쪽의 건에 파열이 없고 관절면 측의 파 


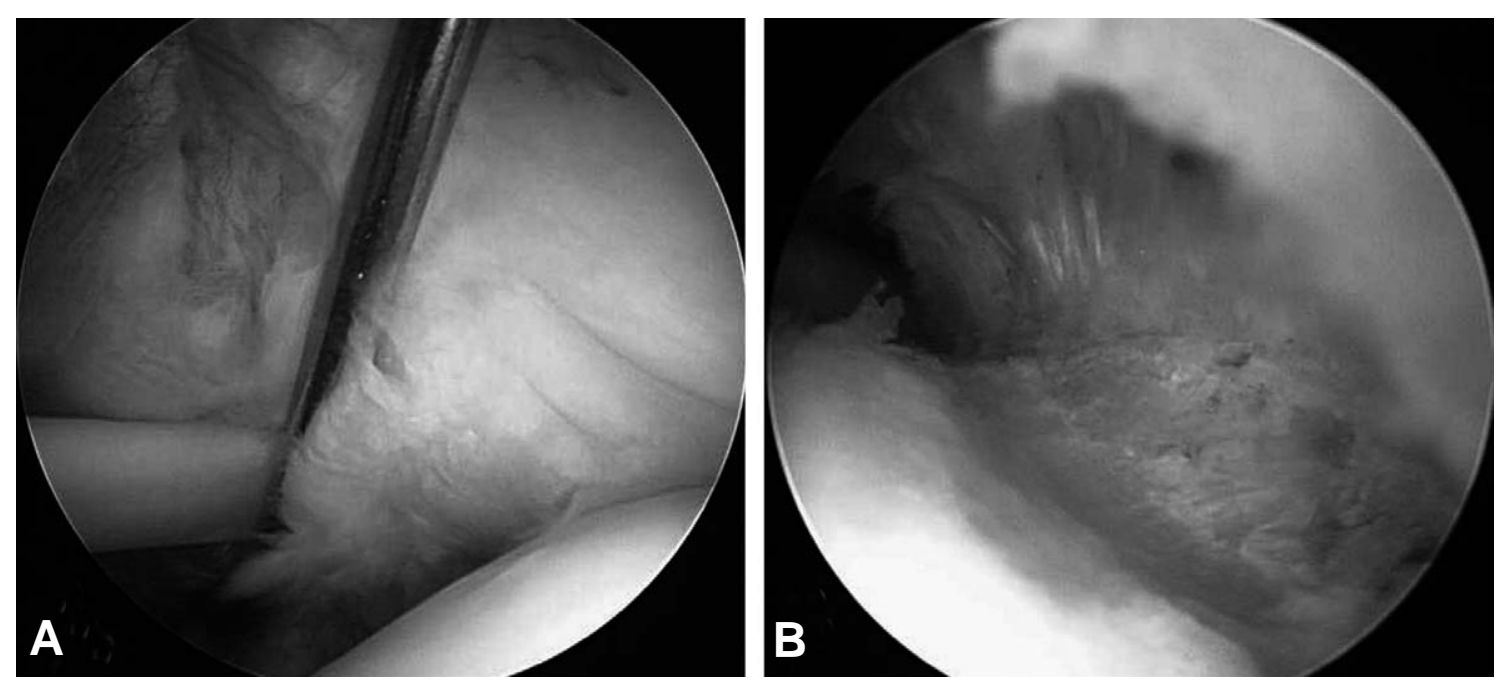

Fig. 2. Procedure of tendon and footprint preparation for intra-articular partial tear of rotator cuff tendon. (A) Arthroscopic intra-articular posterior view shows the PASTA lesion. (B) Posterior view shows the preparation of the humeral footprint with shaver and burr.
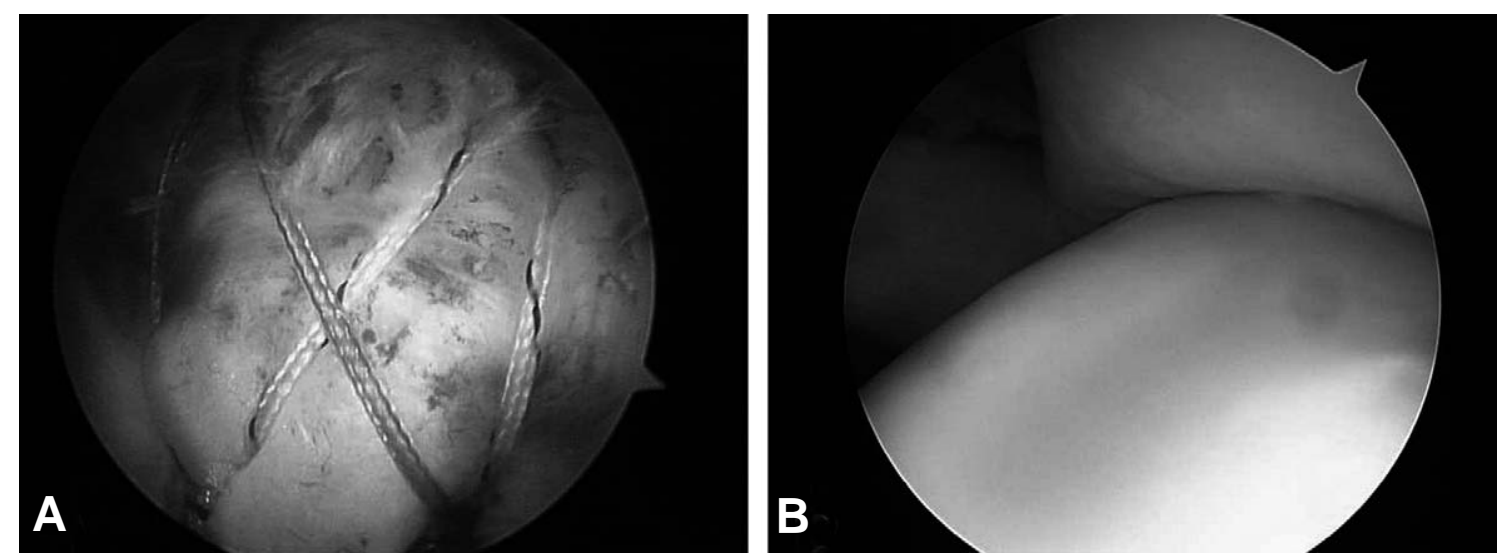

Fig. 3. After knot tying, subacromial and intra-articular view of the rotator cuff. (A) Arthroscopic subacromial view shows the typical triangular suture configuration after tying the knots. (B) Arthroscopic intra-articular posterior view shows the rotator cuff attached to humeral footprint.

열만 확인되면, 남아있는 건을 보존한 상태에서 경건 봉합술을 시행하기 위해 다시 상완 관절 내로 관절경을 옮겼다. 견봉의 외측에 부분 파열로 두께가 얇아진 회 전근 개를 통과하는 척추침을 삽입하여 관절내 회전근 개 부착부의 적절한 위치를 확인하였다. 피부를 절개하 여 bone punch를 통과시킨 후 상완골 관절 연골이 시 작하는 부착부의 가장 내연에 pilot hole을 만들고 5.5 $\mathrm{mm}$ 봉합 나사못 (Corkscrew, Arthrex, Naples, $\mathrm{FL}$ )을 삽입하였다. 봉합 나사못에 연결된 2 쌍의 봉합 사는 봉합사 회수기를 이용하여 전방 삽입구를 통해 관 절 외부로 이동시켰다. 같은 방법으로 회전근 개의 파 열된 외측연에서 $1 \mathrm{~cm}$ 내측으로 건강한 건을 통과시킨 척추침을 통하여 No. 1 Polydioxanone suture (PDS; Ethicon, Somerville, NJ)를 통과시키고 전
방 삽입구를 통해 외부로 이동시켜 봉합사와 연결한 후, 외측연에 있던 $\mathrm{PDS}$ 를 당겨 봉합사를 견봉 외측연 의 피부를 통해 나오도록 하였다. 같은 방식으로 다른 봉합사도 견봉 외측연 피부를 통해 빼내어 각각의 봉합 사가 건재한 회전근 개를 통과하여 견봉하 공간을 통해 견봉 외측연의 피부를 통해 나오도록 하였다. 견봉하 공간으로 관절경을 이동하고 봉합사의 위치를 확인 한 후 외측 삽입구를 통해서 봉합사를 결찰하여 건재한 점 액낭측 건을 하방으로 압박하여 부분 파열된 건이 원래 의 부착부에 놓이도록 하였다. 5 예에 대해서는 경건 일 열 봉합술을 시행하였고, 비매듭 나사못 (PushLock, Arthrex, Naples, FL)이 국내에 사용된 이후 19례에 대해서는 보다 나은 생역학적 효과를 위해 봉합부위 이 후의 2 쌍의 봉합사를 각각 비매듭 나사못에 연결한 후 
Table 1. Preoperative and last follow-up range of motion (ROM)

\begin{tabular}{lccc}
\hline \hline & Preoperative & Last Follow-up & $p$-value \\
\hline Forward elevation & $150.2( \pm 6.67)^{\circ}$ & $170( \pm 5.32)^{\circ}$ & $p<0.001$ \\
Abduction & $148.3( \pm 5.45)^{\circ}$ & $163.1( \pm 4.38)^{\circ}$ & $p<0.001$ \\
External rotation & $75.4( \pm 10.93)^{\circ}$ & $87.7( \pm 11.03)^{\circ}$ & $p<0.001$ \\
Internal rotation & $45.16( \pm 12.26)^{\circ}$ & $62.13( \pm 10.13)^{\circ}$ & $p<0.001$ \\
\hline
\end{tabular}

Table 2. Clinical results of preoperative and last follow-up

\begin{tabular}{lccc}
\hline \hline & Preoperative & Last Follow-up & $p$-value \\
\hline VAS & $7.38( \pm 1.38)$ & $3( \pm 1.38)$ & $p<0.001$ \\
Constant score & $49.25( \pm 5.64)$ & $73.81( \pm 5.64)$ & $p<0.001$ \\
ASES score & $39.59( \pm 12.27)$ & $80.56( \pm 11.36)$ & $p<0.001$ \\
\hline
\end{tabular}

대결절 하방에 삽입하여 회전근 개의 부착부에 수직 압 력을 가하도록 하였다 (Fig. 3).

수술 후 다음날부터 진자 운동 및 수동적 전방 거상 운동을 시작하였으며, 기본적으로 4 주간 외전 보조기를 유지하고 수술 후 8주까지는 정상적인 견관절 운동 범 위를 확보하기 위해 능동적 보조적 관절가동범위 운동 (active assisted ROM exercise)을 시행하였으며, 8 주 이후부터 능동적 관절 운동을 시작하고 12 주째부터 근력 강화 운동을 시작하였다.

\section{통계 분석 방법}

통계적 분석은 SPSS 통계 분석 프로그램 (SPSS for Windows Release 12.0, Chicago, Illinois)을 사용하였고, 수술 전 후의 신체 검사상 관절 운동 범 위, 임상 검사로서 $\mathrm{VAS}$, Constant, 그리고 $\mathrm{ASES}$ 점수를 전산화하여, paired $\mathrm{T}$ test 를 이용하여 95\% 의 신뢰 구간에서 통계적 유의성을 검증하였다.

\section{결 과}

\section{1. 관절운동 범위}

능동적 관절 운동 범위는 수술 전 전방 거상이 평균 $150.2( \pm 6.67)$ 도에서 최종 추시시 평균170 $( \pm 5.32)$ 도로 측정되었고, 외전은 수술 전 평균 $148.3( \pm 5.45)$ 도에서 수술 후 163.1 ( \pm 4.38$)$ 도로 측정되었으며, 외 회전은 수술 전 $75.4( \pm 10.93)$ 도에서 수술 후 87.7 $( \pm 11.03)$ 도로 측정되었다 $(\mathrm{p}<0.001)$. 내회전 운동은 수술 전 평균 $45.16( \pm 12.26)$ 도에서 수술 후 62.13 $( \pm 10.13)$ 도로 향상 되었다 $(p<0.001)$ (Table 1$)$.

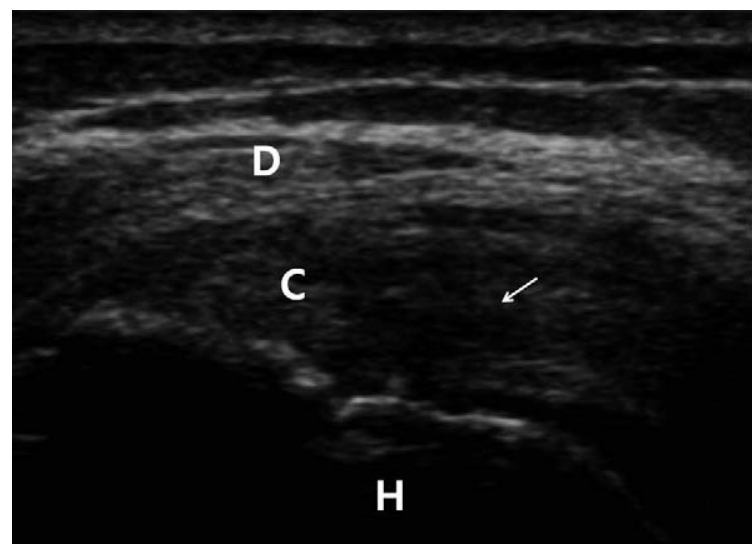

Fig. 4. In 50 years old female patient, post-operative follow-up ultrasonographic image of the shoulder. It shows the deltoid muscle (D), healing appearance (white arrow) of the rotator cuff (C) without re-rupture, and underlying cortex of the humerus $(\mathbf{H})$.

\section{2. 임상적 결과}

$\mathrm{VAS}$ 점수는 수술 전 평균 $7.38( \pm 1.38)$ 점에서, 수 술 후 3 ( \pm 1.38 )점으로 감소하였다 $(p<0.001)$. Constant 점수는 수술 전 평균 $49.25( \pm 5.65)$ 점에서 최 종 추시시 평균 73.81 ( \pm 5.64$)$ 점으로, $\mathrm{ASES}$ 점수는 수술 전 평균 $39.59( \pm 12.27)$ 점에서 술 후 평균 80.56 ( \pm 11.36$)$ 점으로 향상되었다 ( $p<0.001)$ (Table 2). 최종 추시시 환자의 만족도 면에서 24예중 21예 (87.5\%)에서 만족이상의 결과를 보였고, 3 예에서는 동 통 및 관절운동의 감소로 인한 불만족을 나타내었다.

\section{3. 초음파 결과}

최종 추시시 모든 환자에서 시행한 초음파는 방사선 


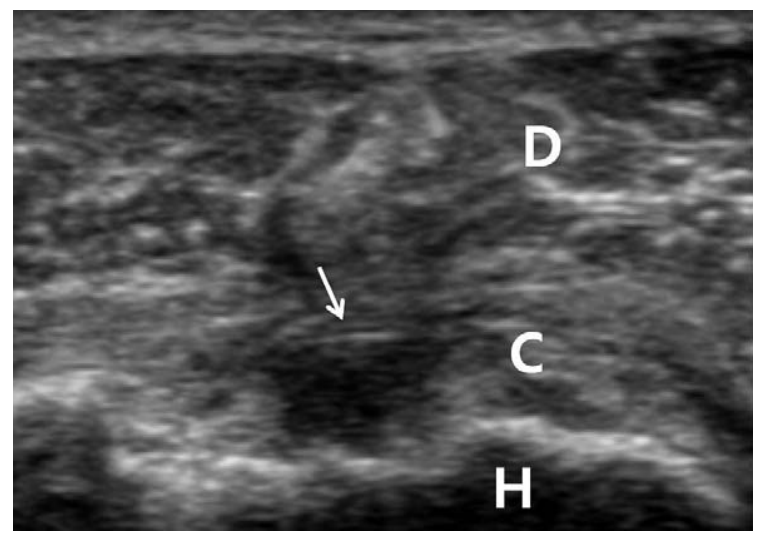

Fig. 5. In 58 years old male patient, post-operative followup ultrasonographic image of the shoulder. It shows increased rupture (white arrow) of the rotator cuff (C). (D) deltoid muscle, $(\mathbf{H})$ humeral head.

과 전문의에 의해 시행되었으며, 초음파 검사 상, 22 예 에서 $(91.66 \%)$ 재파열 소견이 없이 치유되었고 (Fig. 4), 2예에서 $(8.34 \%)$ 증상은 호전되었으나 수술전보다 파열이 증가하여 완전 파열로 진행한 소견을 보였다 (Fig. 5).

\section{고 찰}

본 연구는 회전근 개의 점액낭측 회전근개를 보존 하 면서 관절내 부분 파열에 대해 관절경을 이용한 경건 봉합술을 시행한 후, 평균 37개월 추시상 임상적 및 방 사선학적으로 좋은 결과를 보였고, 환자의 만족도 면에 서 $87.5 \%$ 에서 만족스러운 결과을 얻을 수 있었다. 또 한 최종추시시 초음파을 이용한 회전근개 건 치유는 $91.7 \%$ 에서 유합을 얻을 수 있었다.

회전근 개의 부분 파열은 파열의 위치에 따라서 점액 낭쪽 (bursal-side), 건내 (intratendinous) 및 관절 내 (articular-side) 파열로 분류할 수 있다. Ellman ${ }^{3)}$ 은 파열의 깊이에 따라서 회전근 개 부분파열을 분류하 였는데, grade I은 $3 \mathrm{~mm}$ 미만의 파열, grade II는 3 6 $\mathrm{mm}$ 파열, grade III는 $6 \mathrm{~mm}$ 초과하는 파열에 해당한다. 회전근 개 부분 파열의 원인은 아직 정확하 게 밝혀지지 않고 있지만, 회전근 개의 점액낭면은 관 절낭면 보다 탄성계수가 낮고 최대응력은 커서 동일한 부하에서 관절낭쪽의 회전근 개가 점액낭쪽보다 더 쉽 게 손상을 받는 것으로 알려져 있으며, ${ }^{4)} \mathrm{McConville}$ 등호도 관절내 부분 파열이 점액낭쪽 보다 2 3배 더 많 다고 보고하였다. 점액낭 측에 발생한 파열과, 관절면 측에 발생한 파열은 서로 원인이 다른 것으로 알려져 있다. 관절면 측 부분 파열의 경우 내인성이 주된 원인 으로 알려져 있으며, 극상건의 근건 이행부에서 골 부
착 부위의 $10 \mathrm{~mm}$ 이내까지 비교적 혈관이 적고 반복 적인 전단 응력이 가해지면서 퇴행성 변화가 많이 발생 한다고 하며, 점액낭 측 부분 파열의 경우 오구-견봉 인대나 견봉 전방 $1 / 3$ 에서 반복적인 마찰, 관절와 상완 관절의 불안정성, 내적 충돌 증후군, 반복적인 미세 손 상, 외상 등의 외인성 원인에 의한다고 한다. ${ }^{5-7)}$ 진단적 검사로 초음파나 자기공명 영상 검사가 있으며, 관절면 측 부분 파열에서는 자기공명 관절조영술이 유용하다고 보고된 바 있다. ${ }^{8)}$

부분층 파열에 대한 치료 방법에는 보존적 요법, 변 연절제술, 견봉성형술 그리고 건 봉합술 등 여러가지가 있으며, 단독 혹은 복합적으로 시행될 수 있다. 변연절 제술과 견봉성형술의 결과는 다양하게 보고되는데 Esch 등 9 은 $76 \%$ 에서 만족할 만한 결과는 얻었지만, Oglivie-Harris ${ }^{10)}$ 는 단지 $50 \%$ 에서만 양호 이상의 결 과를 보고 하였다. 회전근 개 부분층 파열은 일반적으 로 시간이 지날수록 점점 더 진행하는 것으로 알려져 있는데, 회전근 개의 파열 후 자연적 경과에 대해서 Yamaguchi 등 ${ }^{11}$ 은 무증상의 회전근 개 파열 환자의 초음파 추적 연구에서 평균 2.8 년에 $51 \%$ 에서 증상이 나타났고 파열의 크기는 감소하지 않았으며, $39 \%$ 의 환 자에서는 파열의 크기도 증가하였다고 보고하였고, Yamanaka와 Matsumoto ${ }^{12}$ 도 40 예의 관절면측 부분 파열에 대한 관절조영술을 통해 평균 13 개월간 $53 \%$ 에 서 파열의 크기가 증가하였고 $28 \%$ 에서는 완전파열로 진행되었으나 단지 $20 \%$ 에서만 부분파열의 크기가 같거 나 줄었다고 보고하여 직접적인 건 봉합술을 통한 적극 적인 치료의 필요성을 인식하게 되었다. 일반적으로 회 전근 개 부분 파열이 $50 \%$ 미만인 경우에 변연 절제술 및 견봉성형술을 시행하는 것이 효과적일 수 있으며, 부분 파열이 $50 \%$ 를 넘는 경우에 봉합술을 시행하는 것 이 효과적인 것으로 알려져있다. Weber ${ }^{13)}$ 는 $50 \%$ 이상 파열된 grade 3 의 회전근 개 부분 파열 환자에서 견봉 하 감압술과 변연절제술만 시행한 경우와 최소 절개 봉 합술을 병행한 경우를 비교하여, 봉합술을 병행한 환자 군의 결과가 더 좋았다고 보고하였다. 저자들도 grade 2 이하의 부분 파열에 대해서는 변연 절제술 및 견봉성 형술을 시행하고 grade 3 의 파열에 대해서 관절경적 봉합술을 시행하였다.

건을 봉합하는 방법으로 부분층 파열을 전층 파열로 만들어서 봉합하는 방법과 정상 부분의 회전근 개를 보 존하면서 파열된 건만을 봉합하는 방법이 있으며, 접근 방법에 있어서는 개방성 방법과 관절경적 방법이 있다. 개방성 방법을 시행할 경우에는 관절면측의 파열 부분 을 수술시야에서 확인 할 수 없으므로 전층 파열로 전 환하는 것이 필요할 수 있다. 또한 관절면측의 파열이 심하거나, 점액낭 측의 파열과 남아있는 건의 퇴행성 
변성이 존재할 경우에도 완전 파열로 전환하여 치료할 수 있다. 최근에는 관절경 기구, 봉합 재료 및 술기의 발전으로 관절경을 통한 다양한 술기들이 소개되고 있 다. Lyons 등 ${ }^{14}$ 이 부분 파열된 건에 대해서 변연 절제 를 시행 한 후 side to side 봉합하여 좋은 결과를 보고 하였다. 하지만 근-골간 봉합 및 정확한 해부학적 위치 에 봉합시키기 위해서 봉합 나사못을 이용한 술기들이 보고 되고 있으며, ${ }^{15.16)}$ 부분층 파열을 전층 파열로 전환 하여 완벽한 부착부 회복을 통해 최대 접촉 면적이 이 루어지도록 하는 방법과 점액낭 측의 건강한 회전근 개 를 완전 파열로 만들지 않고 보존한 채로 봉합 나사못 을 회전근 개에 통과시키는 경 건 봉합술이 있다. Itoi 와 $\mathrm{Tabata}^{17}$ 는 38 예의 회전근 개 부분파열에 대해서 완전 파열로 만든 후 봉합하여 $82 \%$ 에서 만족할 만한 결과를 보고하였다. Waible 등 ${ }^{16}$ 은 점액낭 측의 건 섬 유를 보존한 상태에서 관절내 부분 파열의 병변을 봉합 함으로써 보다 빠른 재활 치료를 할 수 있다는 가능성 을 제시하였고, Gonzalez-Lomas 등 ${ }^{18}$ 은 회전근 개 부 분 파열의 생역학적 사체 연구에서 전층 파열로 전환하 여 봉합한 경우에 비해, 남아있는 건을 보존한 채 경 건 봉합술을 시행한 경우가 더욱 우수하다고 보고하였 다. 신 등 ${ }^{19}$ 은 15 예의 PASTA 병변에 대해 변형된 경 건 봉합술로서 골-건 유합을 좀 더 촉진시킬 수 있다는 가정하에, 경건 봉합술을 시행한 후 비매듭 나사못을 견봉하 공간 내에서 대결절에 적용하여 회전근 개의 족 적에 수직 압력을 가할 수 있는 기법의 수술을 시행한 후 즉시 부분적인 능동운동을 시행하고 우수 이상의 결 과를 보고하였다.

저자들도 좀 더 나은 생역학적 효과를 얻기 위해 봉 합 나사못을 사용하였고 전례에서 점액낭 측의 건 섬유 를 보존하면서 경건 봉합술을 시행하였으며, 국내에 비 매듭 나사못이 들어온 이후에는 회전근 개에 효적인 수 직 압박력을 주기 위해 위해 매듭 이후의 봉합사를 두 개의 비매듭 나사못에 연결하여 대결절 하부에 삽입 하 였다.

본 연구는 한명의 시술자에 의해 이루어 졌으며, 방 사선과 전문의에 의해 초음파를 이용한 회전근개의 유 합을 분석하였고, 동일한 나사못을 이용하여 수술을 시 행하였다는 강점이 있으나, 약점으로는 후향적 연구이 며 임상 결과를 비교할 대조군이 없었고, 초음파 보다 는 더 정확한 자기공명 영상을 통한 추시 관찰을 하지 못한 한계가 있을 것으로 보이며, 보다 정확한 결과를 얻기 위해서는 장기적 추시 관찰을 통한 평가가 필요하 리라 사료된다.

\section{결 론}

회전근 개의 관절면측 $50 \%$ 이상의 부분 파열에서 관 절경적 경 건 봉합술을 시행한 24예에 대해서 평균 37 개월 (19 64개월) 추시 관찰상 만족할만한 임상적 및 초음파 결과를 보였으며, 추천할 만한 술 식으로 사료 된다.

\section{REFERENCES}

1) Fukuda H. The management of partial-thickness tears of the rotator cuff. J Bone Joint Surg Br. 2003;85:3-11.

2) Synder SJ. Arthroscopic treatment of partial articular surface tendon avulsions. Presented at the AAOS/ AOSSM Comprehensive Sports Medicine: The Athletic Perspective to Treatment, Controversies and Problem Solving. Lake Tahoe, NV, February 2001.

3) Ellman H. Diagnosis and treatment of incomplete rotator cuff tears, Clin Orthop Relat Res. 1990;254:6474.

4) Nakajima T, Rokuuma N, Hamada K. Histologic and biomechanical characteristic of the supraspinatus tendon: Reference to rotator cuff tearing. J Shoulder Elbow Surg. 1994;3:79-87.

5) McConville OR, lannotti JP. Partial-thickness tears of the rotator cuff: evaluation and management. $J$ Am Acad Orthop Surg. 1999;7:32-43.

6) Breazeale NM, Craig EV. Partial-thickness rotator cuff tears: pathogenesis and treatment. Orthop Clin North Am. 1997;28:145-55.

7) Burkhart SS, Morgan CD, Kibler WB. Shoulder injuries in overhead athletes: the "dead arm" revisited. Clin Sports Med. 2000;19:125-58.

8) Kwon OS, Park SE, Shin ES. Comparative Study of MR-arthrography and Arthroscopy in Partial Thickness Rotator Cuff Tears. J Korean Shoulder Elbow Soc. 2009; 12:38-43.

9) Esch JC, Ozerkis LR, Helgager JA. Arthroscopic subacromial decompression: Results according to the degree of rotator cuff tear. Arthroscopy. 1988;4:24190.

10) Ogilvie-Harris DJ, Wiley AM. Arthroscopic surgery of the shoulder. A general appraisal. J Bone Joint Surg Br. 1986;68:201-7.

11) Yamaguci K, Tetro AM, Blam O, Evanoff BA, Teefey SA, Middleton WD. Natural history of asymptomatic rotator cuff tears: a longitudinal analysis of asymptomatic tears detected sonographically. J Shoulder Elbow Surg. 2001;10:199-203.

12) Yamanaka K, Matsumoto T. The joint side tear of the rotator cuff: A followup study by arthrography. Clin Orthop Relat Res. 1994;304:68-73.

13) Weber SC. Arthroscopic debridement and acromio- 
plasty versus mini-open repair in the management of significant partial-thickness tears of the rotator cuff. Ortho Clin N Am. 1997;28:79-82.

14) Lyons TR, Savoie FH 3rd, Field LD. Arthroscopic repair of partial-thickness tears of the rotator cuff. Arthroscopy. 2001;17:219-23.

15) Lo IK, Burkhart SS. Transtendon arthroscopic repair of partial-thickness, articular surface tear of the rotator cuff. Arthroscopy. 2004;20:214-20.

16) Waible B, Buess E. Partial-thickness articular surface supraspinatus tears: a new transtendon suture technique. Arthroscopy. 2005;21:376-81.
17) Itoi E, Tabata S. Incomplete rotator cuff tears. Results of operative treatment. Clin Orthop Relat Res. 1992; 284:128-35.

18) Gonzalez-Lomas G, Kippe MA, Brown GD, et al. In situ transtendon repair outperforms tear completion and repair for partial articular-sided supraspinatus tendon tears. J Shoulder Elbow Surg. 2008;17:722-8.

19) Shin SR, Yoo YS, Kim DY, Lee SS, Jeong US, Choi HS. Short-term Outcomes of Arthroscopic Transtendinous Repair in Partial Articular Side Tears of the Rotator Cuff. J Korean Shoulder Elbow Soc. 2008;11:1127.

\section{초 록}

목적: 관절경적 경건 봉합술을 시행한 회전근 개 관절내 부분 파열 환자에 대해 임상적 결과를 분 석 보고하고자 하였다.

대상 및 방법: 2006년 4월부터 2010년 1월까지 회전근 개 관절내 부분 파열로 진단되어 관절경 적 수술을 시행받은 총 31예의 환자 중 경건 봉합술 (transtendon suture technique)을 시행 하고 추시가 가능하였던 24예의 환자를 대상으로 하였다. 환자의 수술 시 평균 연령은 55 세 (27 75)였고, 평균 추시 기간은 37개월 (19 64)이었다. 남자가 10예, 여자가 14 예였으며 24 예 모두 $6 \mathrm{~mm}$ 이상 파열된 Ellman 등급 3 에 해당하였고, 결과 분석은 관절 운동범위, $\mathrm{VAS}$, $\mathrm{ASES}$, Constant 점수를 이용하여 분석하였다. 또한, 영상학적 결과는 초음파를 시행하여 평가 하였다.

결과: 평균 전방 거상 범위는 수술 전 $150.2( \pm 6.67)$ 도에서 최종 추시 시 $170( \pm 5.32)$ 도로 향 상되었고 평균 $\mathrm{VAS}$ 점수는 수술 전 $7.38( \pm 1.38)$ 점에서 최종 추시 시 $3( \pm 1.38)$ 점으로 감소 하였다 $(p<0.001)$. Constant 점수는 수술 전 49.25 ( \pm 5.65$)$ 점에서 최종 추시 시 73.81 (土 $5.64)$ 점으로 향상되었으며, $\mathrm{ASES}$ 점수는 수술 전 39.59 ( \pm 12.27$)$ 점에서 최종 추시 시 80.56 $( \pm 11.36)$ 점으로 향상되었다 $(p<0.001)$. 최종 추시시 만족도 면에서 24 예 중 21 예에서 결과에 만족한다고 하였으며, 3 예에서는 약간의 동통으로 인한 불만족을 나타내었다. 초음파 검사 상, 22 예에서 $(91.66 \%)$ 재파열 소견이 없이 치유되었고, 2 예에서 $(8.34 \%)$ 증상은 호전되었으나 수 술전보다 파열이 증가하여 완전파열로 진행한 소견을 보였다.

결론: 회전근 개 관절 내 부분 파열 환자에 대해 관절경적 경건 봉합술을 시행하고 최소 1 년 6 개 월 이상의 추시에서 양호한 임상적 및 영상학적 결과를 보였다.

색인 단어: 견관절, 회전근 개, 관절내 부분 파열, 관절경, 경건 봉합술 